\title{
Intestacy Reforms - The Way Things Were, 1952
}

\author{
S. M. Cretney*
}

Proposals to reform succession law can arouse strong feelings: the new code of intestate succession introduced as part of the 1925 property legislation ${ }^{1}$ was seen by some ${ }^{2}$ as threatening the traditional landed estates; whilst the proposals in the Law Commission's recent Report Distribution on Intestacy. ${ }^{3}$ denounced as "naive and simplistic" by the authors of the standard practitioners' work ${ }^{4}$ and criticised in somewhat more measured terms by other commentators, ${ }^{5}$ have been rejected by the Government. ${ }^{6}$ In contrast, the Intestates' Estates Act 1952 which effected a major shift in the policy of the law was enacted with little opposition, notwithstanding the fact that some of the issues which have now come to seem intractable had already become the subject of comment. ${ }^{7}$ There may therefore be more than mere antiquarian interest in giving an account, drawing on the official papers which are now available in the Public Record Office, of how that Act came to be enacted. ${ }^{8}$

* Solicitor, Fellow of All Souls College, Oxford. The author is grateful to Mr. D. R. Holloway (see note 41) who kindly read the typescript.

1. Administration of Estates Act 1925, consolidating provisions first enacted in the Law of Property Act 1922.

2. Walter Hume Long, widely regarded as the leader of the country party amongst the Unionists and at the time First Lord of the Admiralty, had his expressed concerns about the possible impact of the reforms on the landed interest allayed by a 12 page letter from the Permanent Secretary in the Lord Chancellor's Department, Sir Claude Schuster; and Long's specific concern that the ending of primogeniture would lead to the break up of the old family estates was met by the argument that such estates were usually held in settlements which would regulate devolution irrespective of the law of intestacy: see letters of 1,9,10 and 12 February 1920 Public Record Office [PRO] files LCO2/443.

3. Law Com. No 187 (1989)

4. Sherrin and Bonehill. The Law and Practice of Intestate Succession (2nd ed. 1994) p. 124.

5. See notably R. Kerridge, "Distribution on Intestacy, The Law Commission's Report" (1990) 54 Conv. 358. 6. See Official Report (HL) 1 July 1993, vol. 547, col. WA 38. The Commission, possibly surprisingly in the light of criticism from commentators and bodies such as The Law Society [see Official Report (HL) 16 June 1922, vol. cols. 170-178], appears to regard the Government's reaction as exemplifying an unsatisfactory attitude to the implementation of Law Reform proposals: see Twenty-Eighth Annual Report 1993 (Law Com. No. 223, paras. 1.14 - 1.23, 3.6 - 3.8.); and note the debate on the second reading of the Law Reform (Succession) Bill, Official Report (HL) 13 February 1995, vol. 561, col. 502. 7. Notably the respective rights of a surviving spouse and the deceased's children.

8. The main files consulted are LCO2/444I, 4443, 4445, 4446, 4447. (Committee on the Law of Intestacy. Evidence, Correspondence with Members); LCO2/4448 (Committee on the Law of Intestacy, Minutes of Meetings); LCO2/4449 (Committee on the Law of Intestacy, Publication of report etc); LCO2/4450 (Committee on the Law of Intestacy, - as to carrying out Report); LCO2/445I (The Intestates' Estates Bill 1951, Correspondence 1951-2); LCO2/4452 (The Intestates' Estates Bill, further correspondence); and LCO2/6671 (The Intestates' Estates Bill 1951, Notes on Clauses). 


\section{SUFFICIENT TO KEEP MUM??}

The Administration of Estates Act 1925 had been based on the principle that the surviving spouse of an intestate should - consistently with the pattern of distribution actually adopted by those who made wills - inherit the whole of all save the largest estates: the survivor had the personal chattels and a legacy of $£ 1,000^{10}$ absolutely, and a life interest in any residue. " But shortly after the end of World War II - notwithstanding the fact that inflation had been, by more recent standards, modest ${ }^{12}$ - concern began to be expressed (both officially ${ }^{13}$ and otherwise ${ }^{14}$ ) about the plight of widows whose husbands had failed to make wills; and particularly about the risk that the matrimonial home would have to be sold in such cases. ${ }^{15}$ Eventually a Parliamentary Question ${ }^{16}$ by Iain Macleod ${ }^{17}$ led the Lord

9. Changes in attitudes over the past half century are vividly demonstrated by a World War II poster preserved in the Public Record Office which sought to increase security consciousness by the slogan "Be like Dad. Keep Mum!"

10. With interest at $5 \%$ from the date of death.

11. If the intestate left issue, the surviving spouse had a life interest in half the residue; and if there were no issue, but certain specified relatives (extending to uncles and aunts of the half blood) survived, the spouse's life interest was extended to the whole estate: Administration of Estates Act 1925, s. 46. The personal representatives could (with the consent of the surviving spouse) redeem a surviving spouse's life interest in consideration of a lump sum reckoned in accordance with tables elected by the personal representatives [Administration of Estates Act 1925, s. 48(1)]. Experience suggested that this power was not extensively used "Perhaps because the existence of this particular Section of the Act is not widely known to personal representatives": Report of the Committee on the Law of Intestate Succession, Cmd. 8130 (1951) para. 32.

12. According to official Indices, it would have been necessary to spend $\mathfrak{f 1}, 700$ in 1948 to buy goods which had cost $£ 1,000$ (the amount of the statutory legacy to a surviving spouse) in 1925 .

13. The Law Society, responding to letters from solicitors inserted a notice seeking views in the Gazette in November 1948; and the Council concluded that a surviving spouse should receive $f 5,000$ irrespective of whether there were children of the marriage: $\mathrm{H}$. Boggis-Rolfe [Lord Chancellor's Office] to the Treasury Solicitor Sir Thomas Barnes, 22 May 1950, PRO file LCO2/4440.

14. A correspondent informed the Lord Chancellor's Office [see PRO file LCO2/4441] that he had had the "Painful duty of having to turn the widow out of the family home on the death of a husband ... and I have just dealt with a case where the husband had to leave the home arising out of the death of the wife. I could recite other tragedies, if necessary."

15. The "inflated value of house property" was referred to as a relevant factor in the Report of the Committee on the Law of Intestate Succession Cmd. 8130 (1951) para. 10; but Lord Chancellor Simonds appears to have deleted the reference to this from his officials' draft of the paper recommending legislation to be submitted to the Home Affairs Committee on 28 November 1951: see the manuscript amendments to the draft in PRO file LCO2/4451.

16. 16 April 1950.

17. He asked the Attorney General to set up a committee on intestacy "particularly in relation to the widow's right to purchase the home where she and her deceased husband have lived". He had earlier written to the Attorney General, Sir Hartley Shawcross referring to a constinuency case in which the deceased's daughter was insisting that the house be put up for auction "which is, I believe, within her rights . . . although the widow's money contributed greatly to the buying of the house".

Macleod, elected in 1950, was a powerful orator who had a meteoric rise to office (becoming Minister of Health in 1952 at the age of 38 on promotion direct from the back benches) but he was not popular with influential right wing conservatives (who thought him " too clever by half" and evidently sometimes found it difficult to accept a man who had earned some part of his living by playing bridge). His sudden death on 20 July 1970 (shortly after being appointed Chancellor of the Exchequer in the Heath government) was thought by other Conservatives to be the loss of one of the best Prime Ministers the country never had: see N. Fisher, Iain Macleod (1973) and R. Shepherd, Ian Macleod (1994) - neither of which mentions the rôle Macleod played in this area - and the entry by Ian Gilmour in the Dictionary of National Biography. 
Chancellor ${ }^{18}$ to favour the appointment of a Committee under Lord Morton of Henryton ${ }^{19}$ to investigate the issue. ${ }^{20}$.

\section{THE GREAT AND THE GOOD?}

It was intended that the Committee should reflect a broad range of interests; and the files show a high level of political involvement in the process of choosing those to be appointed. Advice was taken from a number of Ministers. Herbert Morrison ${ }^{21}$ urged that Members of Parliament should be appointed since such representation gave satisfaction to Parliament and "shows that the Government are fully alive to the fact that Members of Parliament are pre-eminently the spokesmen of the public" and that such appointments add authority and may be of considerable assistance when the time comes to give effect to the Report. ${ }^{22}$ Morrison also thought that there must be "at least one woman ${ }^{23}$, and it is always an advantage to put on somebody from

18. Viscount (subsequently Earl) Jowitt. Jowitt was thought by some to lack political principle. Elected as a Liberal in the General Election in April 1929, he immediately accepted the post of Attorney-General in the Labour Government and joined the Labour Party (as Lord Birkenhead put it, "hurling himself upon the Socialist omnibus as it was turning at full speed into Downing Street".) He was expelled from the Labour Party in 1931 in consequence of accepting office in Ramsay MacDonald's National Govemment: see for a full account, R.F.V. Heuston, Lives of the Lord Chancellors 1940-1970 (1987) Chapter II. In the circumstances his choice of the motto "tenax et fidelis" when raised to the peerage may be thought to have been provocative; but there is no doubt that his tenure of the Great Seal between 1945 and 1951 was distinguished by considerable achievements in law reform.

19. Appointed to the Chancery bench in 1938 he was created a Lord of Appeal in Ordinary in 1947. It has been said (by Sir Denys Buckley in The Dictionary of National Biography 1971-80) that " he possessed a ready and impish sense of humour which won him general friendship and affection. . . . His advocacy was consistently careful, constructive, concise and cogent, and in his judicial judgements he never seemed to find any difficulty in reaching a clear and convincing conclusion lucidly expressed. He was a delightful judge to whom to present an argument but a testing one."

Morton (who had previous experience of public service as deputy chairman of the contraband committee at the Ministry of Economic Warfare and as Chairman of the Council of Legal Education) accepted the invitation; and it was thus unnecessary to approach Denys Buckley (Treasury Junior Counsel 1949-60, and subsequently a Chancery Division judge and Lord Justice of Appeal) or Raymond Jennings QC (subsequently Master of the Court of Protection) who had also been regarded as suitable by the Department. The Permanent Secretary's Deputy, George Coldstream disagreed with a colleague's view that a recently retired county court judge might be asked: Coldstream did not think the judge would be useful members of the Committee and "he certainly ought not to be invited to preside."

20. See the letter from H. Boggis-Rolfe of the Lord Chancellor's Office (subsequently Deputy Permanent Secretary and at one time Secretary to the Law Commission) to Sir Thomas Barnes, the first solicitor to be appointed Treasury Solicitor.)

21. Morrison, the Lord President of the Council and as such responsible for the co-ordination of the Labour Government's policies, was a powerful figure in the Labour Party. He was defeated by Hugh Gaitskell in the leadership election in 1955 for the successor to C.R. Attlee.

22. Morrison to Jowitt, 12 July 1950 , PRO file LCO $2 / 4440$.

23. When the names of the Committee were announced there was adverse comment on the fact that only one woman had been appointed. The National Council of Women of Great Britain had previously urged that a representative be appointed, but were politely rebuffed: 10 August 1950. Ambrose Appellbe, a prominent solicitor of progressive views, wrote on behalf of the Married Women's Trust and protested at the gender imbalance (31 October 1950) as did the Women's Group on Public Welfare (14 December 1950). 
Wales": his specific proposal ${ }^{24}$ of the Labour MP and former school teacher Mrs. Dorothy Rees (whom he described as "a sensible and practical woman") was no doubt welcome. ${ }^{25}$ She was balanced politically by the Conservative MP for Northwich, John Foster, ${ }^{26}$ a lawyer of renowned brilliance: and further legal input was provided by the barrister Michael Albery ${ }^{27}$ and by the solicitor and Labour MP, Eric Fletcher. ${ }^{28}$

Considerable difficulty was experienced in finding a suitable Trade Unionist: Arthur Deakin, the powerful General Secretary of the then 1.3 million strong Transport and General Workers' Union refused to allow Morrison's first suggestion to be appointed, and eventually Lord Kershaw ${ }^{31}$ (to whom Deakin had "no objection") was nominated. Harold Wilson ${ }^{32}$ put forward a number of names of possible employers' representatives and his first choice (Sir Hugh Chance, chairman of a family glass manufacturers, "who manages to find time for a good deal of social work") was appointed.

\section{KEEPING THE COMMITTEE WITHIN BOUNDS}

The Committee's Terms of reference were a matter of great importance to the Lord Chancellor's officials: there was evidently ${ }^{34}$ still considerable sensitivity about

24. In response to Jowitt's doubts as to whether it was really necessary to have someone from Wales, but an expression of readiness to appoint a Welshman who was either a lawyer or had experience of social work: Jowitt to Morrison 28 June 1950.

25. Mrs. Rees was subsequently engaged in much public work and was appointed DBE.

26. Of whom it has rather surprisingly been said that "his public achievement was negligible compared with his private and personal influence which was considerable in England but especially in North America": Miriam Rothschild, Dictionary of National Biography 1981-5.

27. Albery was the author of a work evidently admired within the Lord Chancellor's Office, on the Inheritance (Family Provision) Act 1938.

28. Subsequently ennobled as Lord Fletcher of Islington. It is said that he was the Prime Minister's choice as Solicitor-General in the Labour Government in October 1964, but that the appointment of a solicitor to that office was then regarded as impossible. He became Minister without Portfolio with special responsibility for law reform in that administration: R.F.V. Heuston, Lives of the Lord Chancellors 1940-1970 (1987).

30. On the ground that the person concerned was indispensable to the Union.

31. Kershaw had served as Chairman of Courts of Referees under the Unemployment Insurance Acts.

32. Then President of the Board of Trade: see Wilson to Jowitt 14 September 1950. PRO file LCO2/4440.

33. 1896-1981.

34. The draft terms of reference put by Boggis-Rolfe to the Treasury Solicitor (PRO file LCO2/4440, 22 May 1950) were confined to a consideration of the rights of a surviving spouse on intestacy, and stated that Coldstream and he had "not been able to think of any other subject which could conveniently be considered simultaneously". 
reopening discussion on the powers of the court to override a testator's wishes ${ }^{35}$ and even more to suggestions that the provisions laid down by law of intestacy might be overriden by the exercise of a judicial discretion. Yet any increase in the provision to be made for a surviving spouse on intestacy would inevitably increase the number of cases in which hardship might be caused to others who had been dependent on the deceased. In the end, the terms of reference were skilfully crafted to confine the issues as narrowly as the department thought expedient: the Committee was -

(a) To consider the rights ${ }^{36}$ of a surviving spouse in the residuary estate of an intestate:

(b) To consider whether, and if so to what exent and in what manner, the provisions of the Inheritance (Family Provision) Act 1938 ought to be mde applicable to intestacies; ${ }^{37}$

(c) To report whether any, and if so what, alteration in the law is desirable. ${ }^{38}$

\section{THE COMMITTEE AT WORK ${ }^{39}$}

The Committee worked with what today seems astonishing speed; and the Chairman was able to submit the Report to the Lord Chancellor less than eight months after the Committee had been established. ${ }^{40}$ The Committee's Secretary was evidently

35. Under the powers conferred by the Inheritance (Family Provision) Act 1938 whch had only been enacted after prolonged and sometimes almost bitter controversy: see Tyler's Family Provision (2nd. ed. by R.D. Oughton, 1984) Chapter 1 for an account making use of the Lord Chancellor's Department's records. The Labour Lord Chancellor, Sankey, had favoured legislation on the lines of the much more radical legislation proposed by the National Council of Societies for Equal Citizenship in 1929 [see Sankey to Parmoor, 14 October 1929, PRO file LCO2/1185] but there had been disagreement between Conservative Lord Chancellors: the first Lord Hailsham had been, and remained, an implacable opponent of the legislation; whereas Lord Maugham (whose view was finally that which prevailed in Cabinet) had been prepared to allow Parliament a free choice. Parliamentary Counsel also had views: "I never ceased to say at every opportunity throughout the time whilst I was dealing with it that it appeared to me to be wrong both in conception and in drafting. Consequently no attacks upon it are likely to offend my amour propre"': see Ellis to Coldstream 6 August 1941, PRO file LCO2/1516.

36. Under Administration of Estates Act 1925, s.46; Supra. n.11.

37. This important extension to the terms originally proposed by the Lord Chancellor's officials was urged by the Treasury Solicitor.

38. Report of the Committee on the Law of Intestate Succession Cmd. 8130 (1951) (hereafter referred to as "Morton Report") para. 1.

39. The membership was announced in The Times, 18 October 1950. B.E. Astbury and A.W. Brown were appointed to the Committee in addition to those mentioned in the text.

40. The Report is dated 5 June 1951 and was submitted on 25 June. In contrast, the Law Commission evidently began its study of Distribution on Intestacy in 1987, and completed a Working Paper [No. 108] for consultation on 10 June 1988. Its report [Law Com. No. 187] dated 27 October 1989 was laid before Parliament on 18 December 1989. 
knowledgeable and formidably efficient; ${ }^{41}$ and the Chairman ${ }^{42}$ did not encourage excessively lengthy discussion. ${ }^{43}$ But the main factor influencing such a rapid disposal of what might have been thought complex issues is simply that the Committee seems to have had no doubt that it could itself interpret what it described as the spirit of the age.$^{44}$ Moreover, the Committee accepted ${ }^{45}$ the philosophy adopted in framing the 1925 legislation ${ }^{46}$ that the provisions made by testators provided a sound basis upon which intestate distribution could be based; 47 and it did have available to it a survey of wills proved over a five week period. ${ }^{48}$ The Committee received advice on the law of intestacy in foreign countries ${ }^{49}$, and written memoranda from seven

41. D.R. Holloway. An official in the Probate Registry he subsequently served from 1966 to 1983 as a Registrar of the Principal Registry of the Family Division, and is the author of many books. He produced briefing memoranda which may still be regarded as models of their kind; and also marshalled the statistical evidence (collected in PRO file LCO2/4445) on which the Committee placed some reliance, see infra. n.48.

42. Evidently his chairmanship gave satisfaction in government circles, since he was almost immediately appointed to chair the Royal Commission on Marriage and Divorce. D.R. Holloway was appointed as Assistant Secretary to the Royal Commission. The Royal Commission's report (Cmd. 9678 published in 1956) was far from unanimous, and has been the subject of strong and even intemperate criticism, notably by O.R. McGregor, Divorce in England (1957).

43. The Committee met on only six occasions. The minutes on the fifth meeting give some flavour of the chairman's style: a "long discussion' took place on whether the provisions of the Inheritance (Family Provision) Act 1938 should be extended to total intestacies. The Minutes record an extensive discussion of the issues: and "the Chairman put the following question to the Committee: Do you think that some provision should be made by statute for mitigating cases of hardship which might arise" if the proposal significantly to increase the surviving spouse's rights were adopted? "All the members with the exception of Mr. Eric Fletcher thought that some provision should be made. Mr. Fletcher then said that in view of the general opinion of the other members he was prepared to support the recommendation put forward by the Chairman in the outline of the report. (Mr. Fletcher left the meeting at this stage).": PRO file LCO2/4448.

44. Morton Report para. 10.

45. As had The Law Society: see Boggis-Rolfe to Barnes, 22 May 1950, PRO file LCO2/4440.

46. The Notes for Ministers prepared by officials on the Bill which became the Intestates' Estates Act 1952 state that the draftsman of the 1925 Act, Sir Benjamin Cherry, "incorporated what he believed to be general intention of persons dying intestate. In doing so he acted mainly on his personal knowledge, no comprehensive statistics of disposals by will being available at the time". But it appears that in fact statistics were obtained from the Estate Duty Office in 1921 and that they confirmed the view taken by Cherry: see Memorandum No. 1 to the Morton Committee [PRO file LCO2/4447] p.2.

47. Contrast the cogent criticism of this approach by the Law Commission, Distribution on Intestacy (Law Com. No. 187, para. 4.)

48. Morton Report, para. 18.

49. Prepared by Sir David Hughes Parry, Director of the Institute of Advanced Legal Studies, London University, and author of a still widely used student's text: Parry and Clark, The Law of Succession (9th. ed. 1988 by J.B. Clark). 
organisations, ${ }^{50}$ and it received a large number of written suggestions ${ }^{51}$ (including a petition signed by 3,202 persons urging improvement in the widow's position ${ }^{52}$ ): but the Committee did not seek to dramatise the problems. ${ }^{53}$, and did not even consider carrying out an attitude or other public opinion survey.

\section{THE COMMITTEE REPORTS}

The Committee found no difficulty in reaching agreement on its general policy: it accepted the argument that there had been a considerable depreciation in the value of sterling since the 1925 reforms; and that the matrimonial home was often valued at a sum "greatly in excess" of the statutory legacy, with the result that the surviving spouse might be forced to leave the home which would be sold to satisfy the claims of the deceased's children. ${ }^{54}$ In the result, there was no longer any similarity between the provision made for the surviving spouse by the average testator and that made for the spouse by the law of intestate succession; 55 and, in the Committee's view, it followed that the surviving spouse's share should be increased. ${ }^{56}$.

\section{MORE - BUT HOW MUCH MORE?}

It would hardly have required the appointment of a Committee to reach this conclusion: but deciding on the nature and scale of the increase was much less easy. The Committee drew a distinction between cases where the intestate left surviving issue and other cases. Where there were surviving issue, the Committee decided that a fivefold increase

50. The General Council of the Bar and the Council of the Law Society (who both also gave oral evidence): the Solicitors' Managing Clerks' Association, the Committee of London Clearing Bankers, the Married Women's Association and the National Council of Women of Great Britain. The Marriage Law Reform Society did not disguise the fact that its primary objective was to reform the divorce law so as to permit divorce after the spouses had lived apart for two years rather than to reform the law of intestate succession, but it did prophetically favour giving a person who had lived with the deceased as a spouse for three years the right to make a claim under the 1938 Act ( $c$ Law Com. No. 187. para. 63 - two year cohabitants to be eligible - a proposal to which effect is to be given by the Law Reform (Succession) Act 1995). 51. Although the Morton Report states that most of the private individuals' comments were about particular cases of hardship [para. 2] it should be recorded that Professor Glanville Williams presciently identified the demographic changes reflected in an increasing number of step-parent relationships as a matter which should be taken into account in any reform; and that a particularly powerfully argued letter from a Halifax solicitor, E. Maurice Drake, Solicitor, foreshadowed the recommendation ultimately made by the Law Commission in 1989 that the whole estate should go to the widow leaving other dependants to an application for the exercise of the court's discretion under the inheritance legislation.

52. Morton Report para. 2.

53. The Secretary found it necessary to write on 30 November 1950 to the editor of the Daily Graphic stating that whilst he welcomed "to a limited extent" the publicity which the newspaper had given to the Committee's work, it was "not correct to say that I hear daily of tragedies caused by persons dying intestate. I have no recollection of making a statement of this nature to your reporter and in any event it is not true."

54. Considerable difficulty was caused to the Committee and to officials by the existence of a concession which often led to the home being valued for estate duty purposes at its pre-World War II value: see eg Morton Report para. 25. But unless the contrary is indicated references in this text are to the market values current at the time.

55. Morton Report, para. 16.

56. Supra. n.54 and text. 
(to $£ 5,000^{57}$ ) in the amount of the statutory legacy payable to a surviving spouse $\mathrm{e}^{58}$ would be appropriate ${ }^{59}$. The Committee also made two ancillary proposals in further support of the objective of improving the surviving spouse's position. First, the survivor should be given an option to purchase the matrimonial home at its open market value as at the date of the deceased's death; ${ }^{60}$ and, secondly, the spouse should be entitled ${ }^{61}$ to redeem the life interest in half the remaining estate to which (it was proposed) the survivor should continue to be entitled. ${ }^{62}$

In cases where the deceased left no issue, the Committee recommended a compromise between those ${ }^{63}$ who favoured giving the whole estate to the survivor; ${ }^{64}$ and those who thought that the deceased's kin should also benefit. Where the deceased died without issue but left a spouse and a parent or sibling of the whole blood, the spouse should take a legacy of $£ 20,000$ and half the residue absolutely. The balance of the estate should go to the surviving parent or parents, or (if neither parent survived) to the brothers and sisters of the whole blood. ${ }^{65}$ The Committee did not think the

57. Free of death duty and costs; and the survivor would retain the entitlement to the deceased's personal chattels. The recommended increase in the amount of the statutory legacy was substantially more than would have resulted from adjusting the $f 1,000$ provided by the 1925 Act to take account of general inflation, and was at the upper end of the range of suggestions made by witnesses. Indexation - which would have

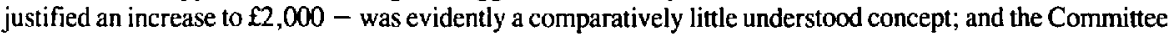
does not seem to have been influenced by it. The Bar Council (virtually alone) had recommended that the legacy remain unchanged, the spouse's position being improved by conferring a life interest in the whole of the deceased's residuary estate: Morton Report, para. 17.

58. The rate of interest payable on this statutory legacy was to be reduced from $5 \%$ to $4 \%$ : Morton Report, paras. 16-22.

59. The statement by Lord Gardiner in moving the second reading of the Family Provision Bill 1966 [ see Official Report 16 June 1966, col. 202] that the Morton Committee had "pointed out that the object of the statutory legacy was to enable the widow to buy the house", that the Committee said that " $£ 1,000$ for this purpose was no use in 1952" and that the proper equivalent, judged in terms of the increase in the price of houses" was $£ 5,000$ does not accurately reflect the Committee's expressed views [see Morton Report, para. 10-21] which took account of inflation in house prices as merely one relevant factor. The Committee (following the precedent of those responsible for the 1925 legislation) was much more influenced by the pattern of testators' wills.

60. Morton Report, paras. 23-27.

61. Under the Administration of Estates Act $1925 \mathrm{~s} .48(1)$ the intestate's personal representatives were empowered to redeem the life interest in accordance with tables they selected; but this procedure was not much used: Morton Report, para. 32. The Committee's proposal (intended to reduce the number of life interests and further to improve the position of the survivor) gave the right to the survivor in accordance with a "simple table . . proportionate to the expectation of life of the surviving spouse" incorporated in the legislation: Morton Report, para. 32.

62. Morton Report, paras. 28-32.

63: Notably, the Council of the Law Society: Morton Report, para.34.

64. "This seems rather a striking proposal. It means that the spouse would take the whole estate even if the intestate left a very large estate. . . We feel that under such circumstances a childless person, dying intestate, would wish that close relatives . . . should take some benefit from the estate, subject always to adequate provision being made for the spouse. It often happens that a large portion of the intestate's estate has been derived from his family and it seems just, therefore, that the family should have an opportunity of sharing in it after the intestate's death. "[Morton Report, para. 34].

65 . On the statutory trusts defined by Administration of Estate Act 1925, s.47, which also provided for substitution of issue of deceased siblings. 
average individual would want relatives more remote than this to benefit from the estate at the expense of the surviving spouse ${ }^{66}$ and accordingly recommended that brothers and sisters of the half blood and their issue, should lose the right ${ }^{67}$ to share in the estate of an intestate who died leaving a surviving spouse. ${ }^{68}$

The general tenor of the Committee's proposals was thus vividly to exemplify what has been described ${ }^{69}$ as the amputation of the blood stock and of the movement of marriage (as compared with genetic kinship) into the foreground. ${ }^{70}$ But the Committee was itself conscious ${ }^{71}$ that the increased provision which it proposed for a surviving spouse might well work injustice in many cases where there were stepchildren by another marriage; and for that reason recommended that the Inheritance (Family Provision) Act 1938 should be made to apply to cases of intestacy. ${ }^{72}$

\section{OFFICIALS DECIDE}

British constitutional practice allows Ministers to seek advice (whether from bodies such as Departmental Committees or from their own Departmental officials or from others $\left.{ }^{73}\right)$; Ministers ${ }^{74}$ decide whether to take such advice and whether and when to promote legislation; ${ }^{75}$ and Parliament decides whether to enact the measures placed before it.

66. Morton Report, para. 36. The surviving spouse was to take the whole estate absolutely if no relatives within the defined class survived.

67. Administration of Estates Act 1925, s.46.

68. Morton report, para. 36. Such relatives were to retain the right to succeed if there were no surviving spouse. 69. By Sundberg, cited by D. Bradley, "Marriage, Family property and inheritance in Swedish law" (1990) 39 I.C.L.O. 370.

70. This thesis is persuasively developed by M.A. Glendon, The New Family and the New Property (Toronto, 1981).

71. Although this was one of the few matters on which the Committee found difficulty in reaching agreement 72. The Committee's terms of reference were (as has been pointed out: supra. ns. $34 \& 35$ ) deliberately restricted to limit the scope of discussion of the 1938 Act; and the Committee at its first meeting on 9 November 1950 had discussed whether it should seek to have them extended. Only John Foster KC dissented from the general consensus not to do so: see Minutes, PRO file LCO2/4448. In the event the Committee clearly found the restriction on the scope of its enquiry embarrassing; and it suggested, "at the risk of travelling outside our terms of reference" that if the Act were to be extended to cover cases of intestacy "opportunity might advantageously be found to remove some of the defects which have come to light in the course of' experience of its working (in particular the restrictions imposed by s. 1(3) and (4)): Morton Report, para. 49. Moreover, the class of dependants who could apply under the Act was restricted - for example, an adult son of the deceased's could only do so if disabled; and it is not surprising that the Committee thought it would "obviously be necessary" to review the whole of the Act closely if it were extended to intestacies, and that it might be thought desirable to enlarge the class of "dependants": Morton Report, para. 51. In the event, no comprehensive review took place until the Law Commission undertook the Review (Second Report on Family Property: Family Provision on Death, Law Com. No. 61, 1974) which formed the basis of the Inheritance (Provision for Family and Dependants) Act 1975.

73. In recent years, the practice of taking advice from personal advisers has increased.

74. Assuming collective responsibility for Cabinet decisions. In practice, crucial decisions will usually be taken by Cabinet Committees - in the present instance the Home Affairs Committee.

75. Or whether to block, preserve neutrality (benevolent or otherwise), or actively to support the small number of bills introduced by private members. 
The relationship between the different actors in this scenario can be subtle: the power of officials to influence matters has been a source of much comment but seems inevitable given their long term involvement in the executive machine. On the other hand, Ministers will have declared policies on some matters (albeit rarely on lawyers' law reform) and certainly cannot routinely force through legislation which their own officials support without regard to opinions expressed in either House of Parliament. The passage of the Intestates' Estates Act 1952 illustrates the working of these relationships in the context of what appeared to be a Bill devoid of almost any political content. ${ }^{76}$.

\section{GOVERNMENT CONSULTATION: NOT QUITE SO SIMPLE AFTER ALL . . .}

The first stage in the decision taking process was for the Lord Chancellor's officials to consult with other officials on the Morton Report's proposals; and, immediately, problems were raised. On one view, the most difficult ${ }^{77}$ was whether the Committee had fully considered the implications of the rule ${ }^{78}$ that the younger of two persons who died in circumstances rendering it uncertain which had survived the younger should be deemed to have survived. Hence, a much increased inheritance might, for example, pass to the family of a young bride killed with her husband in an air crash rather than staying in the husband's family. ${ }^{79}$ Lord Morton candidly told ${ }^{80}$ Coldstream that his Committee had never considered the point and that he did not want to do so. ${ }^{81}$ The Lord Chancellor ${ }^{82}$ came to agree that legislation should provide that the statutory presumption be nullified for the purposes of intestate succession; 83 and the Lord Chancellor's Memorandum to the Home Affairs Committee was settled accordingly.

76. The Morton Committee had been appointed by, and reported to the Labour Government's Lord Chancellor (Jowitt: Supra., n. 18). But that Government was defeated at the General Election on 25 October 1951 and decisions as to implementation fell to Lord Simonds, a man of no political experience who was evidently mystified by his appointment by Winston Churchill (in his last administration). He was a great Chancery lawyer, who sadly is now best remembered for his vigorous criticisms of Lord Denning in the Midland Silicones case [ 1962] AC 446, 459 ("heterodoxy, or, as some might say, heresy, is not the more attractive because it is dignified by the name of reform' ').

77. Raised by the Treasury Solicitor.

78. Law of Property Act 1925, s.184.

79. "We had some very hard cases under the present law during the war ..."

80. According to a note endorsed on a letter from Coldstream to Morton dated 19 November 1951 marked "Not to be sent",

81. Although the point had in fact been put to the Committee by the Quain Professor of Jurisprudence at London University. Professor Glanville Williams.

82. Simonds' manuscript note on a minute from Dennis Dobson dated 26 November 1951: PRO file $\mathrm{LCO} 2 / 4457$

83. See now Administration of Estates Act 1925, s.46(3) as added by Intestates' Estates Act 1952, s. 1(4). The Law Commission [Distribution on Intestacy, Law Com. No. 187, 1989, para. 57] consider that a surviving spouse should only inherit if he or she survives the deceased for a period of fourteen days, and the Law Reform (Succession) Act 1995 incorporates a provision requiring survival. 
Another difficulty - for the Lord Chancellor's officials the greatest difficulty 84 - was in connection with the recommendations relating to the Inheritance (Family Provision) Act 1938: the Committee had pointed out that there were difficulties caused by restrictive provisions incorporated in that legislation ${ }^{85}$ but (Dennis Dobson ${ }^{86}$ plaintively minuted ${ }^{87}$ ) the committee had unfortunately not given any indication of the way in which it thought the Act should be amended. ${ }^{88}$

When the Cabinet's Home Affairs Committee expressed some disquiet ${ }^{89}$ at the implications of the proposals to enhance the spouse's position as they would affect a husband with issue by one marriage who remarried late in life, the Lord Chancellor explained that "it was because of this kind of difficulty" that he proposed amendment of the 1938 Act" to enable the courts to intervene in such cases".90

In the light of this discussion it was agreed that a Bill be drafted. ${ }^{91}$ It was thought better that it should be handed to a private member who had a good place in the ballot for private members' bills and lacked any bill of his own rather than being introduced as part of the Government's legislative programme.

84. Dobson's Minute to Simonds 26 November 1951, PRO file LCO2/4457.

85. Supra., n.72.

86. He subsequently became successively Assistant Permanent Secretary (1954-1968) and Permanent Secretary (1968-1977).

87. And it may be thought - in view of the determination of the Lord Chancellor's officials to confine discussion of the 1938 Act to the barest minimum: see Supra., n.34 - somewhat unjustly.

88. Simonds minuted that it would be better to have a separate Bill dealing with the Family Provision legislation, "But this might, I understand, make it more difficult to get any Bill through": PRO file LCO2/4457. Simonds' manuscript note dated 25 November 1951. In the result, the Lord Chancellor and Home Affairs Committee accepted the officials' recommendation to retain the rule [Inheritance (Family Provision) Act 1938, s.l(1) proviso] that applications be not permitted where the deceased had bequeathed not less than two thirds of his net estate to the surviving spouse and the only other dependant or dependants were a child or children of the suvivor, whilst removing restrictions on the court's powers in ordering provision in the cases with which it had jurisdiction to deal. (The Family Provision Act 1966 finally removed the restriction imposed by the 1938 Act so as to avoid the anomaly whereby a spiteful testator might leave a widow two-thirds of the income of his estate in order to prevent her having any right to apply to the court: see Official Report (HL) 16 June 1966 vol. 275, cols. 203-4. Lord Gardiner's statement that he did not know whether the retention of the relevant proviso in 1952 " was simply a slip" suggests that his attention had not been drawn to his predecessor's advice to the Home Affairs Committee: see PRO file LCO2/4451, 28 November 1951, para.8.

89. The Morton Committee had itself recognised this problem: para 47 ; and the President of the Probate Divorce and Admiralty Division subsequently told Coldstream that "very considerable hardship might be caused by the over-riding preference given to the widow" and that "too much may have been sacrificed for the sake of simplicity": Merriman to Coldstream 5 March 1952, PRO file LCO2/4457.

90. Minutes of Home Affairs Committee, 7 December 1951. As pointed out above [Supra., n.72], however, the court would only be able to intervene on an application by a "dependant" of the deceased, and accordingly no married daughter or adult son could apply unless disabled.

91. The Bill as drafted departed from one recommendation of the Morton Committee (which had taken the view that there should be no special rules for partial intestacies). It was decided that, in the light of the increased size of the statutory legacy, the spouse should be required to bring any benefit taken under the will (or in exercise of any general power of appointment) into account against that provision. 


\section{DRAFTING THE BILL: THE DIFFICULTIES INCREASE . . .}

Although it is true that there may be difficulties in securing agreement to broad issues of policy it is often found that these pale into insignificance when those broad issues have to be translated into the precision required by the English tradition of statutory drafting. The Intestates' Estates Act 1952 provides a remarkable example of this phenomenon.

What, for example, could be simpler than to draft legislation giving effect to the Morton Committee's recommendation that a surviving spouse should have an option to purchase the deceased's interest in the matrimonial home? And yet . . . how was matrimonial home to be defined? How were the interests of purchasers and creditors to be protected? What was to happen if the survivor were under 21 or of unsound mind?

The draftsman did his best but was not satisfied with the result: it is not, of course, the draftsman's job to take views on policy but the draftsman wrote that the difficulties were so great that "the whole of this option" might best be omitted from the Bill.92 After all (he wrote) "the Committee were luke warm about it particularly, as I read between the lines, the legal members"; and there would be no problem in keeping the house for the widow's occupation where the family was harmonious, and so "one is probably legislating for the cases where either side are ready to take any obstructive point, and this subject fairly bristles with debatable points which the drafting must leave open." It seems clear that issues of policy could not easily be segregated from technicalities; the grant of an option to purchase would 93 "simply encourage old ladies to insist on going on living in houses which were far to large for them and against their real interests' 94 .

In the result, the officials came to agree that it was impossible to draft legislation to give effect to the proposal, and the Bill as first presented to Parliament did not seek to deal with the matter. But in the end the practical experience of the solicitors' profession came to the rescue:95 the surviving spouse was to be given the right to require the personal representatives to exercise the "well-tried" powers of

92. A.N. Stainton, who subsequently became First Parliamentary Counsel and (accordingly to the obituary published in The Times on 12 November 1988) was responsible for drafting much tax legislation. The obituarist refers to his analytical mind and prodigious intellect, and to that fact that, although he did not suffer fools gladly, "he would at least allow the fool to leave the room before expressing exasperation". For some deeply felt remarks about difficulties encountered in collaboration between some Law Commission staff and Parliamentary Counsel, see R.T. Oerton, A Lament for the Law Commission (1987) Chapter 6, particularly pp.54-6. For comments on the drafting of the 1952 Act in the light of experience, see infra. n. 100 .

93. Coldstream to the Solicitor-General Sir Reginald Manningham Butler 7 March 1952. The draftsman's attempt to produce clauses conferring an option to purchase had been referred to the Senior Chancery Judge, Vaisey J. and he had made "the most devastating criticism of the proposal" and advised the Lord Chancellor to drop it because legislation would do more harm than good.

94. See to the same effect H. Hylton-Foster's speech on the second Reading of the bill: Official Report (HC) 28 March 1952, Vol. 498, col. 1078.

95. See the correspondence between Coldstream and Horsfall-Turner from 13 March 1952. 
appropriation $^{96}$ in respect of the matrimonial home ${ }^{97}$; and the resultant provisions seem to have given rise to few problems ${ }^{98}$ in practice. ${ }^{99}$

The fertile mind of the draftsman found ${ }^{100}$ many other difficulties; 101 but a Bill was eventually drafted and circulated within Whitehall and elsewhere for comment. Officials, viewing the Bill from their own departmental perspectives, were not slow to accept the invitation. ${ }^{102}$ Some of these comments led to significant

96. Administration of Estates Act 1925, s.141. It was held in Lall v. Lall [1965] I W.L.R. 1249 that the survivor has, prior to appropriation, no equitable interest in property such as to give standing in a possession action brought by registered proprietor; and note the draftsman's concern about the difficulties of deciding how far the Morton Report's "option" would bind third parties.

97. But if the widow were to be given a right to keep the matrimonial home, should she not also be given a right to keep the family business? An amendment to this effect was successfully moved by Barnett Janner MP (later Baron Janner - a solicitor and President of the Board of Deputies of British Jews and himself the son of a small shopkeeper) Official Report (HC), 24 June vol. cols. 22-4; but a firm stand was taken against what Lord Mancroft described as a "Perfectly horrible clause" [Official Report (HC), 29 July 1952, vol. 178, col. 390.] As the draft prepared by officials explaining to Janner why the clause was to be removed put it, leaving the technicalities on one side, "widows are often not the best judges of their own business capacity": PRO file LCO2/4452.

98. But see Re Phelps dec'd [1980] 1. W.L.R. 1501 to the effect that the right could not be exercised where the house was worth more than the amount of the statutory legacy. And note the view of the Law Commission [Law Com. No. 187, para.34] that the interpretation put on this provision in Robinson v. Collins [1975] 1 W.L.R. 309 (value of house to be calculated at date of appropriation rather than at death) had caused problems. The Morton Report envisaged that the survivor's right should be to purchase at the death valuation: para. 25 .

99. See the discussion in Sherrin and Bonehill, The Law and Practice of Intestate Succession (2nd. ed. 1994. It is to be noted that officials were worried that the exercise of the power might be "catastrophic" in some cases (e.g. where the matrimonial home had been a farmhouse) and that accordingly in certain defined cases the right to require appropriation is not exercisable unless the court is satisfied that doing so would not be likely to diminish the value of other assets or make them more difficult to dispose of: see Intestates' Estates Act 1952, Sched.2, para. 2. But it was decided (contrary to tradition) that "the attempt to legislate for every case should be abandoned"'; see Notes on Clauses, PRO file LCO2/6671, p.124. 100. Unfortunately, he did not identify some problems which arose in practice. The drafting of the 1952 Act was criticised by academic writers: see Sherrin and Bonehill, The Law and Practice of Intestate Succession (2nd. ed. 1994); and in the debate on the amending Family Provision Act 1966 the Conservative spokesman took the possibly unprecedented step of apologising for the "considerable errors" which were made: see Official Report (HL) 16 June 1966, vol. 275, col. 210.

101. See in particular his six page letter dated 4 January 1952. Amongst the difficulties raised were (i) The application of the rule in Allhusen v. Whittell (1867) L.R. 4 Eq. 295 to the surviving spouse's legacy (ii) the position if the court made an order under the 1938 Act on the basis of provision which turn out not to be those made in the will (e.g. where a new will is discovered); (iii) were purchasers to be affected by notice that chattels should have gone to the spouse?; (iv) difficulties which were perceived as likely to arise in relation to the requirement that one spouse be proved to have survived the other. The draftsman's comments caused some irritation to the Lord Chancellor's officials; in particular, Stainton's suggestion that the Committee be asked whether they had taken account of the implications of the rule in Allhusen v. Whittell prompted a great deal of departmental research; but ultimately Dobson told the private member to whom the Bill had been allotted (Sir Hugh Lucas-Tooth: see infra. n. 106) that he was not sure that the problem was quite as difficult as Stainton had made it appear "because . . . I think one would find that little notice was taken of the rule in Allhusen v. Whittell": Dobson to Lucas-Tooth 7 January 1952. 102. For example, the Postmaster General was concerned that any extension of the Inheritance (Family Provision) Act 1938 would have implications on the right given to depositors to nominate National Savings accounts and other investments; and his officials were concerned that he should be protected. Coldstream robustly suggested to Stainton that "the best thing to do is to leave this question alone. . ." 20 May 1952. The difficulty that a person could wholly defeat the operation of the 1938 Act by skilful choice of assets which would fall outside the definition of "net estate" in s.5(1) was later taken by the Law Society; but no action was taken until the Law Commission's review [Second Report on Family Property: Family Provision on Death, Law Com. No. 61, 1974] which led to the enactment of Inheritance (Provision for Family and Dependants) Act 1975, s.8. 
change; ${ }^{103}$ but the consultation also revealed doubts about the merits of some of the proposals. In particular, a powerful letter from the President of the Probate Divorce and Admiralty Division, ${ }^{104}$ suggested that too much had been sacrificed for the sake of simplicity and that very considerable hardship might be wrought by the overriding preference given to the widow; and eventually the Legislation Committee asked the Lord Chancellor to consider whether an amendment was needed to reduce the degree of preference given by the Bill to the second spouse in cases of remarriage after divorce. ${ }^{105}$

\section{DIFFICULTIES DO NOT TROUBLE PARLIAMENT}

It was nevertheless decided not to amend the Bill further; and its passage through both Houses of Parliament was skilfully handled by the private members entrusted with its carriage. ${ }^{106}$ There were in fact a number of serious issues of principle which might have been discussed, but (as the Commons spokesman, Hylton-Foster ${ }^{107}$ ) wrote 108 "speed and joviality looked like the easiest way", and in the result the few members who attended the debates 109 were regaled with accounts of "elderly

103. Notably in the method of calculating the amount to be paid by way of redemption of the surviving spouse's life interest: see the Notes on Clauses, pp.15-19, PRO file LCO2/6671. Following advice from the Government Actuary a simple scheme for valuation by reference to the cost of a Post Office Annuity was incorporated into the legislation: Intestates' Estates Act 1952, s.2(2). Subsequently, the withdrawal of Post Office annuities required the scheme to be amended; and it is now provided that the capital value is to be reckoned in such manner as the Lord Chancellor may direct: see Administration of Justice Act 1977, s.28(3) and the tables laid down in the Intestate Succession (Interest and Capitalisation) Order 1983 (S.I. 1374).

104. Merriman to Coldstream 5 March 1952, PRO file LCO2/4451, Lord Merriman had had a difficult relationship with the Department, no doubt in part because of his bitter opposition to the proposals for reform of divorce law and procedure put forward in the Reports of the [Denning] Committee on Procedure in Matrimonial Causes (1946-7): see P. Polden, Guide to the Records of the Lord Chancellor's Department (HMSO 1988) pp.106-109. The situation which arose in relation to the intestacy proposals is the more surprising in the light of Coldstream's acceptance in 1946 that "no such enquiry ought to be allowed to be started unless we are quite sure that it is one which is likely to have the approval of the head of the division concerned': PRO file LCO2/3951.

105. Minutes of meeting 11 March 1952.

106. It had originally been intended that the Bill would be taken through the Commons by the barrister Conservative MP for Hendon South Sir Hugh Lucas-Tooth; but he was appointed Parliamentary UnderSecretary at the Home Office and a substitute had to be found. There was some criticism in the Commons that the Government was using private members' time for what was in substance a Government bill. 107. Harry Hylton-Foster had been elected Conservative MP for York in 1950, and subsequently became Solicitor-General (1954-9) and Speaker of the House of Commons (1964-5).

108. To Coldstream 29 October 1952.

109. Officials voiced concern about the unrepresentative nature of the debates: the House of Commons Second reading Debate was "a very thin house" with few speakers. (In fact the House was in fact counted out on 28 March, but the second reading was carried "on the nod" ' in the following week. The Committee debate was "very meagre"; and officials regretted that the Bill had had so little consideration because there were "many questions of principle" on which any Government would want a free vote (e.g. the size of the statutory legacy). The only point of principle urged with any conviction was by Charles FletcherCooke the barrister Conservative MP for Darwen who successfully objected to the further discrimination proposed by the Morton Committee against relatives of the half blood: the Bill was amended to allow brothers and sisters (and uncles and aunts) of the half-blood to retain their right to succeed in default of any spouse, issue, or parent of the deceased, ranking after relatives of the whole blood in the same degree. 
gentlemen who marry little blonde creatures much younger than themselves in the autumn of their days" 110 and other witticisms. ${ }^{\prime \prime \prime}$

\section{THE SIGNIFICANCE OF THE 1952 LEGISLATION}

The Intestates' Estates Act 1952 may, at first sight seem to have been of little long term significance; but in reality by emphasising the primacy to be accorded to the claims of a surviving spouse it constitutes a decisive landmark in the evolution of the law. The Act is also significant in a number of other respects: for example, for the first time in English statute law it recognised the family home as an asset which deserved special protection. Perhaps of even greater significance was the acceptance of the principle that, since no general code for intestate distribution could achieve satisfactory results in every case, the court should be given power to vary the statutory provisions if they failed to make reasonable provision for the deceased's dependants.

This paper has, however, been primarily concerned with the process whereby the legislation came to be enacted rather than with the merits of change in the substantive law: and in this respect the following points may be made.

\section{(i) Preparing public opinion.}

The Morton Committee is a classic example of the technique of preparing the way for legislation by establishing a comparatively broadly based group of people from outside Government to make recommendations. The use of the Committee technique is all the more striking since it seems that there was little dispute that the provision made by the 1925 legislation for the surviving spouse of an intestate had become inadequate.

The Morton Committee was the last occasion on which this technique was used in this context: in 1966, Government felt sufficiently confident to decide on reforms without formal outside consultation; ${ }^{112}$ whilst the most recent proposals have been

110. H. Hylton-Foster, Official Report (HC) 28 March 1952, vol. 498: col. 1083.

111. The Conservative peer, Lord Mancroft, (at the time a Member of the Bar Council), was entrusted with the carriage of the Bill in the House of Lords. His light-hearted speech on the Second Reading Debate in the House of Lords was evidently skilfully attuned to the mood of the House. The Administration of Estates Act had, he said, been drafted by the late Sir Benjamin Cherry, and contained a table of "a complexity and confusion equal only to that in the Table of Affinity in the Prayer Book, concluding with certain nefarious characters which could have stepped only from the pages of Saki or P.G. Wodehouse - namely, aunts of the half-blood. I never met a case of a man being disinherited by a half-blooded aunt, but presumably Sir Bejamin Cherry did not want to take any risks!" [Official Report (HC) 29 July 1952 vol. 178, col. 390]. A humorous reference to the possibility that Lord Chancellor Jowitt [see supra. n. 18] might solve his housing problems by moving into the vicarage at Bray offended Jowitt to the point that he subsequently always left the Lords' Chamber whenever Mancroft spoke [Heuston, supra. n. 18 p.80]; but Mancroft's parliamentary skills were subsequently put to good effect in securing the enactment of the Marriage (Enabling) Act 1960 which rationalised the rules governing the prohibited degrees of marriage.

112. The newly established Law Commission was however informally consulted by the Lord Chancellor: Official Report (HL) 16 June 1966, vol. 275, col. 203. 
made by the Law Commission, a body composed exclusively of professional lawyers. ${ }^{113}$

One advantage of the Committee technique is to give notice that issues on which people may have strong views are being discussed; and thereby to some extent to familiarise the community with the proposals which are being considered. It may be that some recent experience - notably with the Child Support Act 1991 - supports the view that comparatively open discussion carried out over a period of time has some value in accustoming the community to what is proposed.

\section{(ii) Parliament and Law Reform.}

The passage of the Intestates' Estates Act 1952 through Parliament demonstrates the weakness of the parliamentary process as a means of ventilating serious issues in which there is no particular party interest. It was difficult to engage the interest of MPs; and the concern of those with carriage of the Bill was inevitably to minimise the possibility of matters being pursued in a way which could jeopardise the prospects of the Bill becoming law. ${ }^{114}$ Study of the parliamentary process on this and other occasions may be thought to give further weight to the arguments in favour of a special procedure for dealing with technical measures of law reform ${ }^{115}$ and engender scepticism about the wisdom of the decision of a majority of the House of Lords in Pepper v. Hart ${ }^{116}$ to allow reference to the Official Report of proceedings in Parliament in certain circumstances.

(iii) The technicality of law reform.

Above all, study of the background to the 1952 Act reveals the high level of technicality involved even in legislation which might be thought, at first impression, to be comparatively simple and the major part in that process which is played by the Parliamentary Counsel. Who, for example, could have predicted that the Morton Committee's proposal that a surviving spouse should be given the option to purchase the matrimonial home would raise so many technical problems that it was decided it should be abandoned?"1?

113. Family Law, Distribution on Intestacy (Law Com. No. 187, 1989). The Law Commission did, in accordance with its usual practice, engage in a fairly wide consultation exercise: and on this occasion (unusually) it did rely on the results of a survey of public opinion.

114. For a further remarkable example see S.M. Cretney, "The Forfeiture Act 1982: The Private Member's Bill as an Instrument of Law Reform"' (1990) 10 Ox J.L.S. 289.

115. See the discussion of this issue in the Law Commission's Twenty-Eighth Annual Report 1993 (Law Com. No. 223, paras. 1.11-1.21.).

116. [1993] A.C. 593.

117. The fact that an alternative was adopted demonstrates that the executive is not all-powerful; and that if a particular aim has sufficient informed support a Government will find difficulty in resisting suggestions that some technique be found to achieve it. 
(iv) Not for all time, but for a decade or two?

Finally, the history of the 1952 Act demonstrates that legislation of this kind has only a limited life expectancy. Leaving aside the rapid inflation of the sixties and seventies - which led to what would at one time have been thought to be the constitutionally highly objectionable decision to leave the fixing of intestate succession to the virtually uncontrolled discretion of the Government - some of the problems which could be swept under the carpet in 1952 (notably the conflict of interest which may arise when a surviving spouse is not the parent of the intestate's children) have, half a century later, come to assume a degree of importance which can no longer be ignored. The fact that the Law Commission's recent report on Distribution on Intestacy fails adequately to grapple with this issue has led inevitably to the Commission's proposals being rejected. ${ }^{118}$

118. Law Com. No. 187 (1989). Some of the reforms recommended by the Law Commission in that Report are to be given effect by the Law Reform (Succession) Act 1995. For a discussion of the main issue of principle see S. M. Cretney, "Reform of Intestacy: The Best We Can Do?"' (1995) 111 LQR 77; and note the second reading debate on the Law Reform (Succession) Bill: Official Report (HL) 13 February 1995, vol.561, col.502. 